\title{
Fas Receptor and Neuronal Cell Death after Spinal Cord Ischemia
}

\author{
Kohji Matsushita, ${ }^{1}$ Yongqin Wu, ${ }^{1}$ Jianhua Qiu, ${ }^{1}$ Loic Lang-Lazdunski, ${ }^{1}$ Lorenz Hirt, ${ }^{1}$ Christian Waeber, ${ }^{1}$ \\ Bradley T. Hyman, ${ }^{2}$ Junying Yuan, ${ }^{3}$ and Michael A. Moskowitz ${ }^{1}$
}

${ }^{1}$ Neuroscience Center and 2Alzheimer's Disease Research Unit, Massachusetts General Hospital, Harvard Medical School, and ${ }^{3}$ Department of Cell Biology, Harvard Medical School, Boston, Massachusetts 02129

Cell death from spinal cord injury is mediated in part by apoptotic mechanisms involving downstream caspases (e.g., caspase-3). Upstream mechanisms may involve other caspases such as procaspase-8, a $55 \mathrm{kDa}$ apical caspase, which we found constitutively expressed within spinal cord neurons along with Fas. As early as $1.5 \mathrm{hr}$ after transient ischemia, activated caspase-8 (p18) and caspase- 8 mRNA appeared within neurons in intermediate gray matter and in medial ventral horn. We also detected evidence for an increase in death receptor complex by co-immunoprecipitation using Fas and anti-procaspase-8 after ischemia. At early time points, Fas and p18 were co-expressed within individual neurons, as were activated caspase-8 and caspase-3. Moreover, we detected p18 in cells before procaspase-3 cleavage product (p20), suggesting sequential activation. The appearance of cytosolic cytochrome $c$ and gelsolin cleavage after ischemia was consistent with mitochondrial release and caspase-3 activation, respectively. Numerous terminal deoxynucleotidyl transferase-mediated DNA nick end-labelingpositive neurons contained p18 or p20 (65 and $80 \%$, respectively), thereby supporting the idea that cells undergoing cell death contain both processed caspases. Our data are consistent with the idea that transient spinal cord ischemia induces the formation of a death-inducing signaling complex, which may participate in caspase- 8 activation and sequential caspase- 3 cleavage. Death receptors as well as downstream caspases may be useful therapeutic targets for limiting the death of cells in spinal cord.

Key words: caspase-8; caspase-3; spinal cord ischemia; Fas; DISC; cell death
Spinal cord injury after trauma or cerebral ischemia is a major cause of morbidity and mortality (Kouchoukos, 1991; Von Oppel et al., 1994; Cheshire et al., 1996). Many injured cells die by a necrotic mechanism characterized by disruption of nuclear and cell membranes and disintegration of cytoplasmic organelles (Garcia et al., 1995). Some cells die by a mechanism resembling apoptosis, as evidenced by caspase activation (Hara et al., 1997; Endres et al., 1998; Namura et al., 1998; Springer et al., 1999).

Caspases are important mediators of ischemic cell death. Procaspase-8 [Fas-associated death domain protein (FADD)-like interleukin- $1 \beta$ converting enzyme or MORT1-associated CED-3 homolog] is a $55 \mathrm{kDa}$ initiator caspase (Boldin et al., 1996; Fernandes-Alnemri et al., 1996; Muzio et al., 1996). Procaspase-8 can process itself after ligation of the Fas-tumor necrosis factor family of death receptors (Kischkel et al., 1995; Los et al., 1995; Medema et al., 1997). Fas, a $45 \mathrm{kDa}$ membrane receptor, forms a death-inducing signaling complex (DISC) with an adaptor protein, FADD, and procaspase-8 (Nagata and Goldstein, 1995; Nagata, 1997). Active caspase- 8 initiates downstream cleavage of caspase- 3 by direct or mitochondrial-dependent mechanisms via $\mathrm{BH} 3$ interacting death domain agonist cleavage, leading to apoptosis (Kuwana et al., 1998; Stennicke et al., 1998). In addition, activated caspase-3 may cleave procaspase-8 (Slee et al., 1999; Woo et al., 1999), thereby amplifying the death process.

Procaspase-3 is a $32 \mathrm{kDa}$ protein constitutively expressed within brain (Namura et al., 1998) and spinal cord (Hayashi et al., 1998). On activation, caspase- 3 cleaves $>40$ different substrate proteins,

Received May 11, 2000; revised June 15, 2000; accepted June 26, 2000.

This work was supported by National Institutes of Health Stroke Program Project 5 P50 NS10828 and National Institutes of Health Grant 1 R01 NS374141. We acknowledge Kristy Kikly and Giora Z. Feuerstein (SmithKline Beecham) for advice and use of caspase antibodies. We also acknowledge Jean-Paul Vonsattel (Massachusetts General Hospital) for advice and Carolyn J. Smith for technical assistance.

Correspondence should be addressed to Dr. Michael A. Moskowitz, Massachusetts General Hospital, 149 13th Street, Room 6403, Charlestown, MA 02129. E-mail: Moskowitz@helix.mgh.harvard.edu.

Copyright (C) 2000 Society for Neuroscience $0270-6474 / 00 / 206879-09 \$ 15.00 / 0$ including cytoskeletal proteins, repair enzymes, protein kinases, and transcription factors (Stroh and Schulze-Osthoff, 1998). Inhibition of caspase-3 activation blocks apoptotic cell death within the ischemic CNS (Hara et al., 1997; Chen et al., 1998; Endres et al., 1998) or during embryological development (Kuida et al., 1996; Srinivasan et al., 1998). Procaspase-3 can be activated by at least two mechanisms, which involve cleavage by the active form of caspase-8 (Srinivasula et al., 1996; Scaffidi et al., 1998).

To explore the potential importance of apoptotic cell death in spinal cord, we developed a mouse model of spinal cord ischemia involving transient clamping of the left subclavian artery, aorta, and left internal mammary artery for $11 \mathrm{~min}$ followed by recirculation (Lang-Lazdunski et al., 2000). In this model, blood flow decreases in superficial distal spinal cord to $<30 \%$ of baseline and recovers to baseline after reperfusion. The spinal cord lesion extends from T8 to L5 with little evidence of white matter injury at $5 \mathrm{~d}$. More than $80 \%$ of animals develop sustained paraplegia.

We used this newly developed mouse model to examine caspases and related upstream mechanisms of potential importance to ischemic spinal cord injury. We demonstrate for the first time in vivo the co-existence of activated caspases within single cells undergoing cell death and evidence favoring assembly of a death-receptor complex under neuropathological conditions.

\section{MATERIALS AND METHODS}

Ischemic models. Animal care and experimental protocols complied with The Principles of Laboratory Animal Care (Guide for the Care and Use of Laboratory Animals, National Institutes of Health publication 86-23). The operative procedures to produce transient spinal cord ischemia were performed using a previously described method (Lang-Lazdunski et al., 2000). Briefly, C57BL6 mice (male and female, 18-23 gm; Charles River, Wilmington, MA) were anesthetized with $3 \%$ halothane and maintained on $1-1.5 \%$ halothane in $100 \% \mathrm{O}_{2}$ using a Fluotec 3 vaporizer (Colonial Medical, Amherst, NH). The operative field was exposed by a cervicothoracic incision followed by thoracotomy along the left sternal border. A clip was first placed on the left internal mammary artery. The exposed aortic 
arch and left subclavian artery were then gently isolated and cross-clamped between the left common carotid artery and the left subclavian artery and next at the origin of the left subclavian artery for $11 \mathrm{~min}$ followed by reperfusion. Core body temperature was monitored using a rectal probe and maintained at $36.5^{\circ} \mathrm{C}$ by a heating pad (FHC, Brunswick, ME). Subsequently, the animals were kept warm in a $31^{\circ} \mathrm{C}$ incubator. Only animals showing paraplegia were selected for study $(n=121$ of 145$)$. Mice were killed at $1,1.5,3,6,12,18$, and $24 \mathrm{hr}$. Unless otherwise indicated, at least five animals were used per data point.

Physiology. In a subgroup of animals, we monitored physiological parameters as described elsewhere (Lang-Lazdunski et al., 2000). Briefly, the left femoral artery was cannulated for arterial blood pressure and blood gas measurement. Arterial blood samples (40 $\mu \mathrm{l})$ were analyzed for $\mathrm{pH}$, arterial oxygen pressure $\left(\mathrm{Pa}_{\mathrm{O}_{2}}\right)$, arterial pressure of carbon dioxide $\left(\mathrm{Pa}_{\mathrm{CO}_{2}}\right)$, and base excess using a Ciba-Corning Diagnostics (Medfield, MA) 178 PH blood gas analyzer before thoracotomy and 10 min after reperfusion.

Immunoblotting. Protein samples were extracted from the ischemia zone (T8-L5). Excised tissue was immediately frozen and crushed into powder in liquid $\mathrm{N}_{2}$ and gently homogenized on ice using buffer A [10 mM HEPES buffer, $\mathrm{pH}$ 7.6, $42 \mathrm{mM} \mathrm{KCl}, 5 \mathrm{mM} \mathrm{MgCl}_{2}, 1 \%$ SDS, $1 \mathrm{~mm}$ phenylmethylsulfonylfluoride (PMSF), 1 mM EDTA, 1 mM EGTA, 1 mM dithiothreitol, $1.5 \mu \mathrm{M}$ pepstatin, $2 \mu \mathrm{M}$ leupeptin, and $0.7 \mu \mathrm{M}$ aprotinin]. The solution was then centrifuged at $20,800 \times g$ for $30 \mathrm{~min}$ at $4^{\circ} \mathrm{C}$.

Cytoplasmic and membrane fractions were isolated from fresh tissue as described by Bossy-Wetzel et al. (1998) with minor modifications. Briefly, fresh spinal cord tissue was homogenized in a glass Dounce homogenizer and a B pestle with buffer B $(220 \mathrm{~mm}$ mannitol, $68 \mathrm{~mm}$ sucrose, $50 \mathrm{~mm}$ piperazine- $N^{\prime}, N^{\prime}$-bis(ethanesulfonic acid)-KOH, pH 7.4, $50 \mathrm{~mm} \mathrm{KC1,} 2 \mathrm{~mm}$ $\mathrm{MgCl}_{2}, 5 \mathrm{~mm}$ EGTA, $1.5 \mu \mathrm{M}$ pepstatin, $1.5 \mu \mathrm{m}$ leupeptin, and $1 \mathrm{mM}$ PMSF; 10 strokes). Homogenates were then spun at $16,000 \times g$ for $15 \mathrm{~min}$ at $4^{\circ} \mathrm{C}$. The supernatant (cytoplasmic fraction) was collected with a Pasteur pipette, and the pellet (membrane fraction) was further homogenized on ice using buffer A. The protein content of the different supernatants was assayed (Bio-Rad Laboratories, Hercules, CA). Ten micrograms of total protein or 2-10 $\mu \mathrm{g}$ of cytoplasmic and membrane proteins were subjected to SDS-PAGE and then transferred to a polyvinylidene fluoride membrane (Immobilon-P; Millipore, Bedford, MA). Five percent nonfat milk in TBS/T (10 mM Tris, pH 8, $150 \mathrm{~mm} \mathrm{NaCl,} \mathrm{and} \mathrm{0.05 \%} \mathrm{Tween} \mathrm{20)} \mathrm{was} \mathrm{used}$ to reduce nonspecific binding. The blot was probed with polyclonal antisera raised in rabbits, directly against procaspase-8 (SK441, 1:1000), active form of caspase-8 (SK439, 1:1000), affinity-purified rabbit polyclonal antibody against Fas (1:500; Santa Cruz Biotechnology, Santa Cruz, CA), antisera against gelsolin (1:10,000; Kothakota et al., 1997), or monoclonal antibodies against cytochrome $c(1: 750,7$ H8.2C12; PharMingen, San Diego, CA) or cytochrome oxidase subunit I (1 $\mu \mathrm{g} / \mathrm{ml}$, ID6-E1-A8; Molecular Probes, Eugene, OR) at $4^{\circ} \mathrm{C}$ overnight. Membranes were then washed with TBS/T three times and then exposed to horseradish peroxidaseconjugated anti-rabbit or anti-mouse $\mathrm{IgG}$ for $1 \mathrm{hr}$ at $25^{\circ} \mathrm{C}$. Proteins of interest were detected using the enhanced chemiluminescence (ECL) Western blotting detection system kit (Amersham Pharmacia Biotech, Arlington Heights, IL). The blots were exposed to Hyperfilm (ECL; Amersham, Oakville, Ontario, Canada). In each blot, $\alpha$-tubulin was used as an internal standard.

Densitometry was performed on all gels. The relative density of bands was analyzed by an M4 imaging system (Imaging Research, Inc., St. Catherines, Ontario, Canada). Differences in band density were analyzed by paired Student's $t$ test. $p<5 \%$ was considered significant.

To confirm antiserum specificity, primary antisera (SK441 and SK439) were preadsorbed with full-length $(4 \mu \mathrm{g} / \mathrm{ml})$ or fully cleaved human caspase- 8 protein $(8 \mu \mathrm{g} / \mathrm{ml})$ at $4^{\circ} \mathrm{C}$ overnight, respectively.

Immunoprecipitation. To study whether ischemia or the addition of anti-CD95 antibody to Jurkat cells increased formation of a Fas deathreceptor complex as reported previously, C57BL6 mice were subjected to 11 min of spinal cord ischemia and killed at 3, 6, 12, and $24 \mathrm{hr}$ after reperfusion. Jurkat cells (American Type Culture Collection, Mannasas, VA) were maintained in RPM I 1640 medium supplemented with $10 \%$ fetal bovine serum, $100 \mathrm{U} / \mathrm{ml}$ penicillin, and $100 \mu \mathrm{g} / \mathrm{ml}$ streptomycin. These cells were treated with $100 \mathrm{ng} / \mathrm{ml}$ Fas (anti-human CD95 antibody; PharMingen) for 1, 2, and $3 \mathrm{hr}$. Both tissues and cells were placed in lysis buffer (20 mm Tris-HCl, pH 7.5, 140 mm NaCl, 1\% Triton X-100, 2 mm EDTA, $1 \mathrm{~mm} p$-amidinophenyl methanesulfonyl fluoride hydrochloride, $50 \mathrm{~mm}$ $\mathrm{NaF}, 1 \mathrm{~mm} \mathrm{Na} \mathrm{VO}_{4}, 10 \mathrm{mg} / \mu \mathrm{l}$ aprotinin, and $10 \%$ glycerol), homogenized, and centrifuged. The supernatants (30 mg of protein) were precleared by incubation with protein G-agarose and normal rabbit IgG for $2 \mathrm{hr}$ at $4^{\circ} \mathrm{C}$. These samples were incubated with $2 \mu \mathrm{g}$ of anti-Fas antibody (M-2; Santa Cruz) at $4^{\circ} \mathrm{C}$ overnight or by $2 \mu \mathrm{g}$ of anti-caspase- 8 antibody (H-134; Santa Cruz) and then incubated with protein $\mathrm{G}$-agarose for $1 \mathrm{hr}$ at $4^{\circ} \mathrm{C}$. The immunoprecipitates were washed five times with radioimmunoprecipitation assay buffer $(50 \mathrm{~mm}$ Tris- $\mathrm{HCl}, \mathrm{pH} 7.5,0.1 \%$ SDS, $0.5 \%$ deoxycorticosterone, $1 \% \mathrm{NP}-40$, and $62.5 \mathrm{~mm} \mathrm{NaC1}$ ) and subsequently solubilized in sample buffer.

The immunoprecipitates were separated by $8-16 \%$ SDS-PAGE and transferred to an Immobilon-P membrane. After blocking with 5\% nonfat milk in TBS/T, the membrane was incubated with anti-procaspase- 8 antibody (SK441, 1:1000) or by Fas antibody (see above) and then incubated with the appropriate horseradish peroxidase-conjugated secondary antibody. Detection of procaspase- 8 , Fas, or $\beta$-actin was achieved using an ECL system (Amersham, Buckinghamshire, UK). Procaspase- 8 was also determined in spinal cord homogenates by immunoblotting. The relative density of bands was analyzed by an M4 imaging system.

Immunohistochemistry. Spinal cord (T12-L2) plus attached bone and muscle were removed rapidly en bloc and quickly frozen in liquid $\mathrm{N}_{2}$ vapor. Ten-micrometer sections were cut on a cryostat (HM505E; Microm, Walldorf, Germany) and thaw-mounted onto precleaned glass slides and kept at $-80^{\circ} \mathrm{C}$ until use. Thawed sections were dried completely and post-fixed in absolute ethanol at $-20^{\circ} \mathrm{C}$ for $10 \mathrm{~min}$. After several washes in $0.1 \mathrm{M} \mathrm{PBS}$, the sections were incubated with $10 \%$ normal goat serum (NGS) containing $0.3 \%$ Triton $\mathrm{X}-100$ for $1 \mathrm{hr}$ at $25^{\circ} \mathrm{C}$. Immunohistochemical staining for caspase-8, caspase-3, or Fas was performed using the following rabbit polyclonal antisera: SK441 (1:500), SK440 (recognizes caspase-8, p18, 1:500), SK398 (recognizes active form of caspase-3, p20, 1:500) (Velier et al., 1999), or purified rabbit polyclonal anti-Fas antibody (1:100; Santa Cruz). Antisera or antibody were diluted in $2 \%$ NGS, $0.3 \%$ Triton X-100, and $0.1 \% \mathrm{NaN}_{3}$ in PBS and then incubated at $4^{\circ} \mathrm{C}$ for $72 \mathrm{hr}$. After three rinses in PBS, sections were incubated for $1 \mathrm{hr}$ at $25^{\circ} \mathrm{C}$ with biotinylated goat anti-rabbit IgG (1:300; Vector Laboratories, Burlingame, CA). After washing, the sections were incubated with streptavidin-conjugated $\mathrm{Cy} 3$ or Cy2 (1:1000; Jackson ImmunoResearch, West Grove, PA) in PBS containing $1.5 \%$ NGS for $30 \mathrm{~min}$ at $25^{\circ} \mathrm{C}$.

To identify the phenotype of cells containing the mature and active forms of caspase-8, active caspase-3, and Fas, the sections were then incubated with NeuN monoclonal antibody (1:300; Chemicon, Temecula, $\mathrm{CA})$ as a neuronal marker or $\mathrm{Cy} 3$-conjugated mouse monoclonal glial fibrillary acidic protein (GFAP) antibody (1:300; Sigma, St. Louis, MO) at $4^{\circ} \mathrm{C}$ overnight. The sections stained by NeuN were visualized after incubation with Bodipy fluorescein-conjugated goat anti-mouse IgG secondary antibody (Bodipy FL, 1:200; Molecular Probes, Eugene, OR) for $1 \mathrm{hr}$ at $25^{\circ} \mathrm{C}$. After washing with PBS, sections were dehydrated in ascending ethanol series, immersed in xylene, and coverslipped with Permount (Fisher Scientific, Pittsburgh, PA). Alternating sections were subjected to preadsorption by incubating SK440, SK398, or Fas with fully cleaved human caspase- 8 protein $(5 \mu \mathrm{g} / \mathrm{ml})$, caspase-3-specific peptide (glycine-isoleucineglutamic acid-threonine-aspartic acid, $5 \mu \mathrm{g} / \mathrm{ml}$ ), or Fas specific-peptide (20 $\mu \mathrm{g} / \mathrm{ml}$; Santa Cruz) at $4^{\circ} \mathrm{C}$ overnight. Immunoreactivity before and after preadsorption was then compared.

Double labeling of caspase-8 and Fas. To detect the colocalization of caspase- 8 (pro and active forms) with Fas receptor protein in cells, we performed double staining using primary antisera to caspase- 8 and purified Fas antibody. Biotinylated Fas antibody was generated using a FluoReporter Mini-Biotin-XX protein-labeling kit (F-6347; Molecular Probes). Sections were incubated with SK441 or SK440 as above, and signals were directly visualized with $\mathrm{Cy} 3 \mathrm{FL}$-conjugated anti-rabbit IgG antibody. Sections were then incubated with biotinylated anti-Fas antibody at $4^{\circ} \mathrm{C}$ for $72 \mathrm{hr}$, followed by the incubation with $\mathrm{Cy} 2 \mathrm{FL}$ streptavidinconjugated secondary antibody at $25^{\circ} \mathrm{C}$ for $30 \mathrm{~min}$.

All sections above were analyzed on a Leica DMRB/Bio-Rad MRC 1024 confocal microscope with a krypton-argon laser. For Bodipy FL or $\mathrm{Cy} 2$, the excitation filter was $488 \mathrm{~nm}$, and the emission filter was $522 \mathrm{~nm}$. For Cy3, excitation and emission filters were 568 and $585 \mathrm{~nm}$, respectively. For terminal deoxynucleotidyl transferase (TdT)-mediated DNA nick-end labeling (TUNEL) and Fas, procaspase- 8 , caspase- 8 p18, and caspase-3 p20 histochemistry, positive cells were counted from at least three tissue sections taken from upper, mid, and lower levels (T12-L2) per animal.

In situ hybridization. Before in situ hybridization, sections were thawed, air-dried, and fixed by immersion in $4 \%$ paraformaldehyde in $0.1 \mathrm{M} \mathrm{PBS}$ for $20 \mathrm{~min}$ and then treated with $3 \mathrm{mg} / \mathrm{ml}$ proteinase $\mathrm{K}$ for $30 \mathrm{~min}$ at $25^{\circ} \mathrm{C}$. Sections were blocked with $0.25 \%$ acetic anhydride $\left(10 \mathrm{~min}\right.$ at $\left.25^{\circ} \mathrm{C}\right), 0.2 \mathrm{~N}$ $\mathrm{HCl}\left(20 \mathrm{~min}\right.$ at $\left.25^{\circ} \mathrm{C}\right)$, and $0.1 \mathrm{M}$ triethanolamine $\left(10 \mathrm{~min}\right.$ at $\left.25^{\circ} \mathrm{C}\right)$. After dehydration in alcohol and delipidation with $100 \%$ chloroform, the sections were air-dried. Digoxigenin (DIG)-labeled antisense and sense oligonucleotide probes to mouse caspase- 8 were synthesized in a tailing reaction containing $1 \mu \mathrm{g}$ of oligonucleotide, $50 \mathrm{U}$ of terminal transferase, $5 \mathrm{~mm} \mathrm{CoCl}$, and $0.2 \mathrm{~mm}$ DIG-dUTP (Boehringer Mannheim, Indianapolis, IN). Labeled probe concentrations were determined according to the manufacturer's instructions. The antisense oligonucleotide specific for 


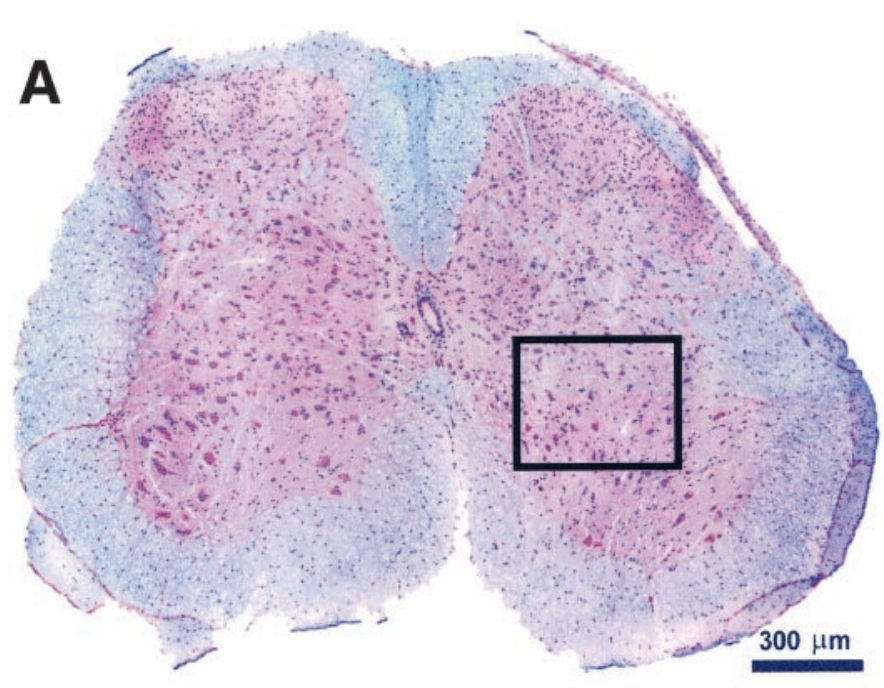

mouse caspase-8 is 5'-CCACGAGATTCTAGAAGGCTACCAAAGCGC-3' (GenBank accession number AJ 000641; nucleotides 721-740). Probes were diluted in hybridization buffer $[50 \%(\mathrm{v} / \mathrm{v})$ formamide, $5 \times \mathrm{SSC}$ (750 mM NaCl and $75 \mathrm{~mm}$ sodium citrate), $20 \%$ (v/v) blocking solution (Boehringer Mannheim, Indianapolis, IN), $0.1 \%$ (w/v) $N$-lauroylsarcosine, and $0.02 \%(w / v)$ SDS] to achieve a final concentration of $25 \mathrm{fmol} / \mathrm{ml}$. Prehybridization was performed at $45^{\circ} \mathrm{C}$ for $2 \mathrm{hr}$, and then hybridization with the probe was conducted at $45^{\circ} \mathrm{C}$ overnight in a humidified chamber with $50 \%$ formamide. Posthybridization washes were performed in decreasing salt concentrations $(2,1$, and, $0.25 \times$ SSC) twice for $15 \mathrm{~min}$ for each at $37^{\circ} \mathrm{C}$. The probe was detected by anti-DIG alkaline phosphatase (Boehringer Mannheim) and visualized by nitro-blue tetrazolium/5bromo-4-chloro-3-indolyl-phosphate (Boehringer Mannheim) per the manufacturer's instructions. The specificity of in situ hybridization was
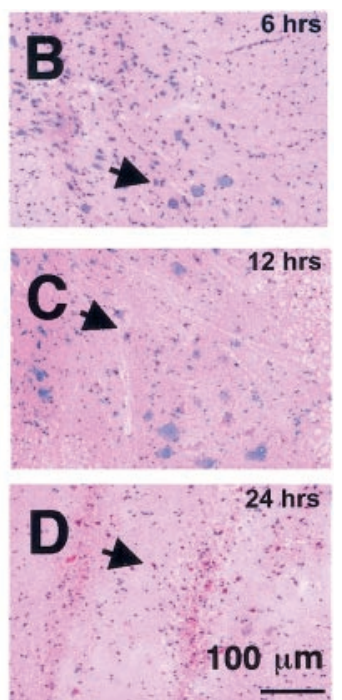

Figure 1. Histopathology of ischemic spinal cord (L1) after $11 \mathrm{~min}$ of ischemia and reperfusion. Degenerated red neurons (arrows) distribute mainly in intermediate gray and ventral horn with normal myelin staining after $6(A, B), 12(C)$, or $24(D)$ hr of reperfusion (Luxol fast blue counterstained with hematoxylin and eosin). determined by antisense and sense probes on adjacent sections. No staining was observed when either probe or anti-DIG antibody was omitted or when sections were pretreated with RNase.

Reverse transcription-PCR. Total RNA was isolated from normal or ischemic spinal cord reperfused for 1, 3, 6, 12, 18, and $24 \mathrm{hr}$ by using TRIzol reagent (Life Technologies, Rockville, MD). One microgram of total RNA was treated with $1 \mathrm{U}$ of amplification grade DNase I (Life Technologies) to eliminate residual genomic DNA and then was reverse transcribed into first-strand cDNA using oligo-dT primer and $200 \mathrm{U}$ of Superscript II reverse transcriptase (Life Technologies). By using firststrand cDNA as a template, the specific primers for caspase- 8 and the $\beta$-actin housekeeping gene were subjected to PCR amplification. The number of cycles and reaction temperature conditions (below) were optimized to provide a linear relationship between the amount of input
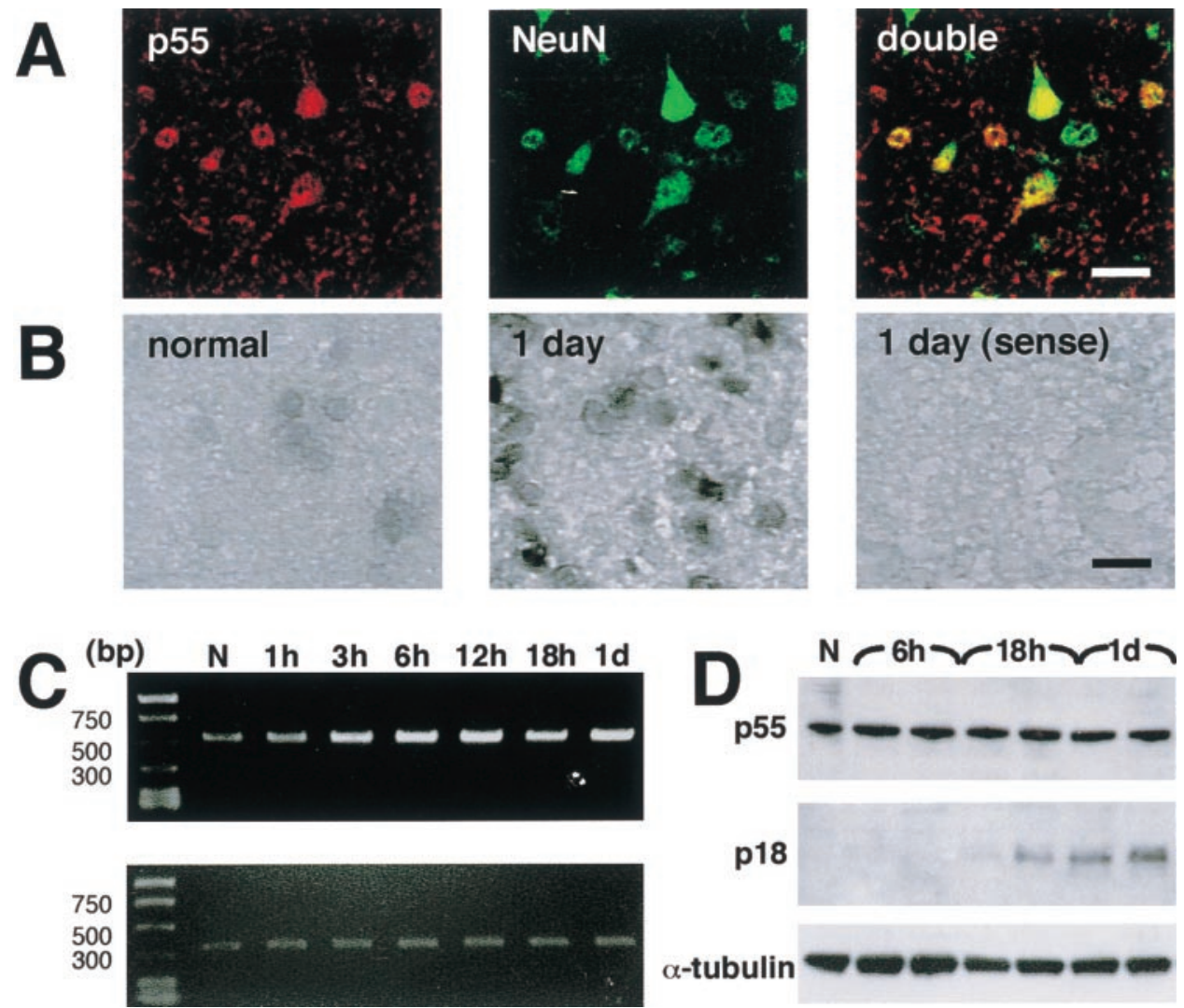

$\alpha$-tubulin
Figure 2. Caspase-8 mRNA and protein in normal $(N)$ and ischemic spinal cord. $A$, Procaspase-8 p55 protein was constitutively present in normal spinal neurons. p55 (red) was detected predominantly in NeuNpositive (green) cells within intermediate gray matter. $B$, Caspase- 8 mRNA was detected in normal spinal neurons by in situ hybridization with a digoxigenin-labeled antisense oligonucleotide probe. It was upregulated in ischemic neurons $1 \mathrm{~d}$ after reperfusion (middle panel). The sense probe did not detect hybridization signals in an adjacent section. Scale bars, $20 \mu \mathrm{m}$. $C$, Caspase- 8 mRNA was upregulated as early as $3 \mathrm{hr}$ after reperfusion and remained elevated as late as $1 \mathrm{~d}$, as detected by semiquantitative RT-PCR (top panel). $\beta$-Actin was used as a housekeeping gene (bottom panel). Results are representative of three separate experiments. $D$, Immunoblot demonstrating procaspase- 8 p 55 constitutively expressed in normal spinal cord. After ischemia, p55 remained unchanged, but p18 appeared sometime between 6 and $18 \mathrm{hr}$ after reperfusion. $\alpha$-Tubulin was used as an internal standard. Each lane is from a separate animal. Results are representative of six individual experiments. 

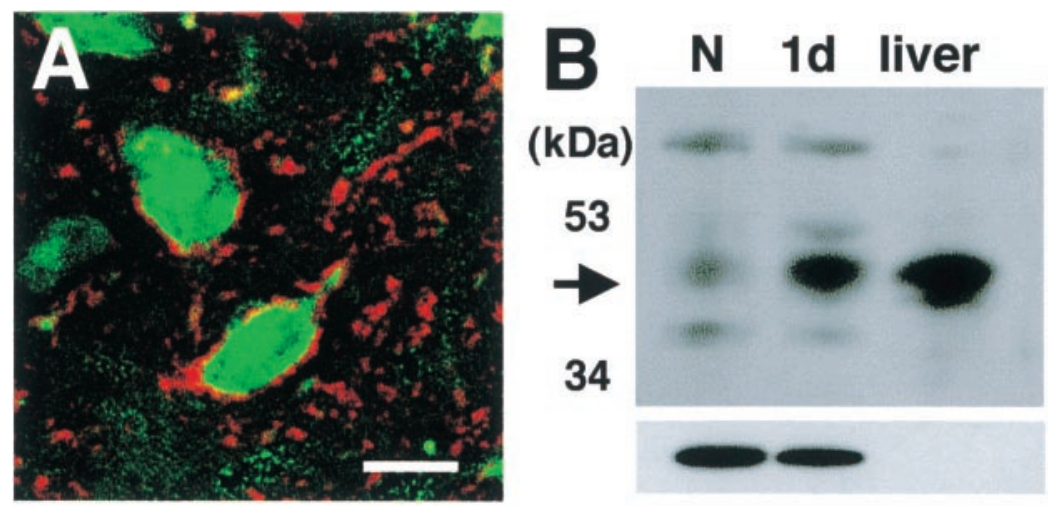

Figure 3. Fas expression in normal and ischemic spinal cord neurons. $A$, Fas immunoreactivity ( $r e d$ ) was observed on the surface of NeuN-positive (green) cells within the anterior horn of normal spinal cord. $B$, Fas $(45 \mathrm{kDa}$, arrow) was expressed in normal spinal cord and upregulated after ischemia at 24 but not $12 \mathrm{hr}$ (data not shown). Normal liver was used as a positive control, and $\alpha$-tubulin was used as an internal standard (bottom panel). C, Fas immunoreactivity ( green) was observed in 10 $20 \%$ of caspase-8 p55-positive (red) cells (top panels), whereas Fas immunoreactivity (green) was observed in $>50 \%$ of caspase-8 p18-positive (red) cells (bottom panels) in medial aspect of ventral horn $6 \mathrm{hr}$ after reperfusion. Scale bars, $20 \mu \mathrm{m}$.
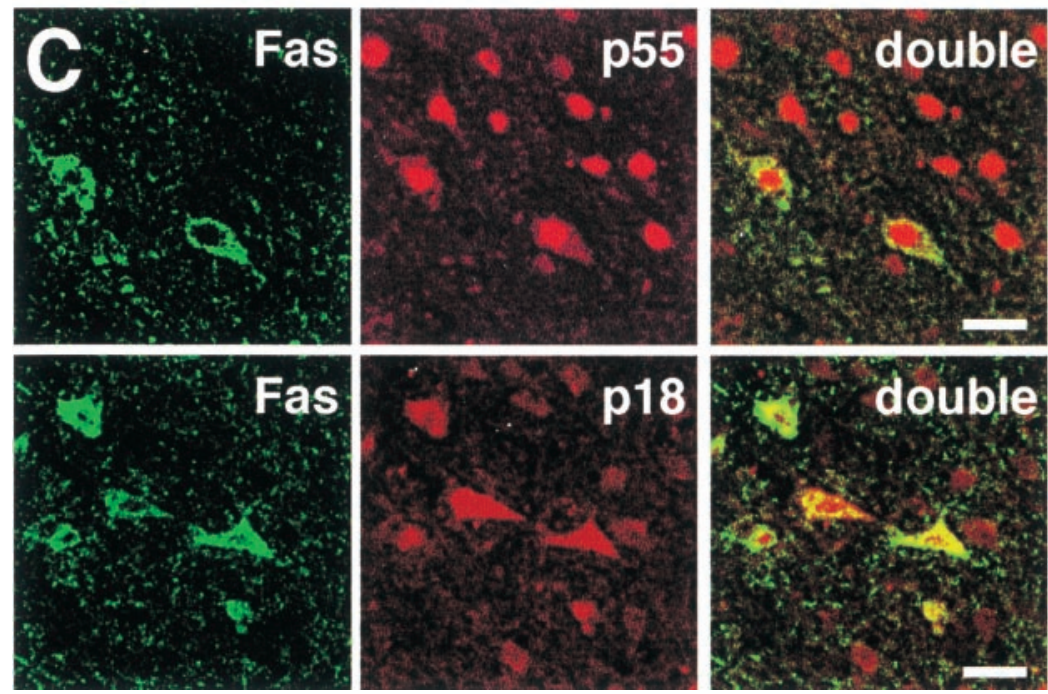

template and the amount of PCR product. Primers for mouse caspase- 8 were $5^{\prime}$-GGCATCTGCTTTCCCTTGTTC-3' and 5'-ATCTTACGACGACTGCACTGC-3' (Sakamaki et al., 1998). cDNA was amplified for 30 cycles, consisting of $94^{\circ} \mathrm{C}$ for $30 \mathrm{sec}, 60^{\circ} \mathrm{C}$ for $45 \mathrm{sec}$, and $72^{\circ} \mathrm{C}$ for $1 \mathrm{~min}$. Primers for mouse $\beta$-actin were $5^{\prime}$-GACCTGACAGACTACCTCAT-3' and $5^{\prime}$-AGACAGCACTGTGTTGGCTA-3', and the condition was $95^{\circ} \mathrm{C}$ for $1 \mathrm{~min}, 55^{\circ} \mathrm{C}$ for $1 \mathrm{~min}$, and $72^{\circ} \mathrm{C}$ for $1 \mathrm{~min}, 25$ cycles. PCR was performed in The DNA Engine (Peltier thermal cycle, model PTC-200; MJ Research, Watertown, MA). After amplification, $10 \mu$ l products were subjected to a $1 \%$ agarose gel and visualized by ethidium bromide staining. The relative density of bands was analyzed by the M4 imaging system.

TUNEL staining. To confirm the presence of cell death by an apoptoticlike mechanism TUNEL staining was performed according to the method of Gavrieli et al. (1992) with minor modifications. Briefly, after staining with primary and secondary antisera, sections were incubated with TdT buffer (30 mm Tris, $\mathrm{pH} 7.2,140 \mathrm{~mm}$ sodium cacodylate, and $1 \mathrm{~mm}$ cobalt chloride) containing TdT enzyme $(0.5 \mathrm{U} / \mathrm{ml}$; Boehringer Mannheim, Indianapolis, IN) and biotin-16-dUTP (0.04 mM; Boehringer Mannheim) for 1 $\mathrm{hr}$ at $37^{\circ} \mathrm{C}$. The reaction was terminated by incubating with $300 \mathrm{~mm} \mathrm{NaCl}$ and $30 \mathrm{~mm}$ sodium citrate for $15 \mathrm{~min}$ at $25^{\circ} \mathrm{C}$. After washing with $50 \mathrm{~mm}$ Tris-HCl, pH 7.7, sections were incubated with streptavidin-conjugated $\mathrm{Cy} 3$ in PBS containing $1.5 \%$ NGS for $30 \mathrm{~min}$ at $25^{\circ} \mathrm{C}$. After three washes in Tris- $\mathrm{HCl}, \mathrm{pH} \mathrm{7.7,} \mathrm{the} \mathrm{sections} \mathrm{were} \mathrm{dehydrated} \mathrm{in} \mathrm{ascending} \mathrm{ethanol}$ series. After immersion in xylene, the sections were coverslipped in Permount.

DNA laddering. DNA was isolated using a QIAamp tissue kit (Qiagen, Valencia, CA). DNA concentration was determined by measuring its absorbance at $260 \mathrm{~nm}$. DNA damage was assessed by a radioactive endlabeled method by terminal transferase (Tilly and Hsueh, 1993) with minor modifications (Endres et al., 1998). The DNA samples were labeled together with $\left[\alpha-{ }^{32} \mathrm{P}\right]$ dideoxy-ATP $(25 \mu \mathrm{Ci}$; Amersham, Oakville, Ontario, Canada) and $25 \mathrm{U}$ of terminal transferase (Boehringer Mannheim) in a final volume of $50 \mu \mathrm{l}$. The reaction was stopped by addition of $5 \mu \mathrm{l}$ of 0.25 M EDTA, $\mathrm{pH}$ 8.0. Labeled DNA was separated from unincorporated radionucleotide by adding a $0.2 \times$ volume of $10 \mathrm{M}$ ammonium acetate and a $3 \times$ volume of ice-cold $100 \%$ ethanol and incubating at $-80^{\circ} \mathrm{C}$ for $60 \mathrm{~min}$. The DNA was pelleted by centrifugation at $15,000 \times g$ at $4^{\circ} \mathrm{C}$ for $30 \mathrm{~min}$, washed with $80 \%$ ethanol, and allowed to air dry for 10 min with tubes inverted. The pellets were resuspended in $20 \mu \mathrm{l}$ of Tris-EDTA buffer, $\mathrm{pH}$ 8.0. Three micrograms of the labeled DNA were electrophoresed on a $2 \%$ agarose gel (agarose 3:1; Amersco, Solon, $\mathrm{OH}$ ) at $50 \mathrm{~V}$ for $3.5 \mathrm{hr}$, with 200 bp DNA fragments (Invitrogen, Carlsbad, CA) as markers. The agarose gels were placed on several sheets of Whatman (Madistone, UK) 3MM chromatography paper and dried in a slab gel dryer (model 224; Bio-Rad, Rockville Centre, NY) for $1 \mathrm{hr}$ without heat. Dried gels were sealed in a plastic bag and exposed to Eastman Kodak (Rochester, NY) X-Omat films at $25^{\circ} \mathrm{C}$ for $6 \mathrm{hr}$. The experiment was repeated three times.

\section{RESULTS}

\section{Physiology}

Separate animals $(n=5)$ were used to determine physiological variables during spinal cord ischemia. Baseline mean femoral artery blood pressure before and after thoracotomy was $70.9 \pm 3.3$ and $53.7 \pm 3.9 \mathrm{mmHg}$ (mean $\pm \mathrm{SD})$, respectively. During ischemia mean femoral artery blood pressure dropped to $10.0 \pm 1.8 \mathrm{mmHg}$ and recovered after reperfusion. The values for arterial $\mathrm{pHa}$, $\mathrm{Pa}_{\mathrm{Co}_{2}}, \mathrm{~Pa}_{\mathrm{O}_{2}}$ and base excess before versus after ischemia were $7.32 \pm 0.03$ versus $7.26 \pm 0.08$ (paired $t$ test, $p>0.05$ ), $47.3 \pm 2.3$ versus $31.3 \pm 6.5 \mathrm{mmHg}(p<0.05), 477.9 \pm 32.5$ versus $239.5 \pm$ $127.7 \mathrm{mmHg}(p<0.05)$, and $-2.8 \pm 1.9$ versus $-11.9 \pm 2.3(p<$ $0.05)$, respectively.

\section{Histopathology}

Three to six hours after reperfusion, eosinophilic staining appeared in the cytoplasm of medium- and small-sized neurons 


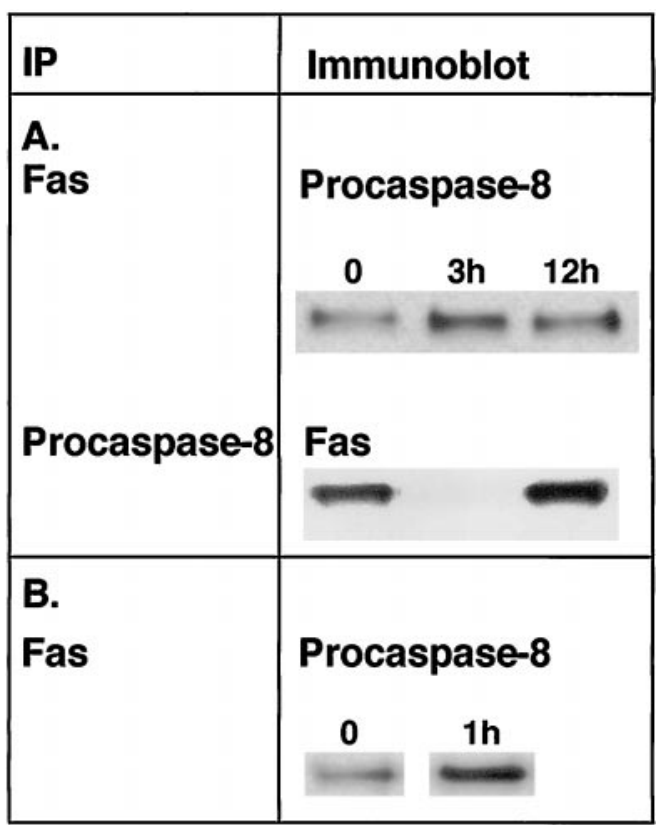

Figure 4. Increase in Fas-procaspase-8 death receptor complex after spinal cord ischemia $(A)$ and Jurkat cell incubation with anti-CD95 antibody $(B)$. C57BL6 mice were subjected to $11 \mathrm{~min}$ of ischemia and killed at the indicated times. Fas receptor and procaspase-8 $(A)$ were immunoprecipitated as described in Materials and Methods. The immunoprecipitates were then probed on an immunoblot using either anti-caspase- 8 or anti-Fas antibody. Bands corresponding to heavy- and light-chain IgG are not shown. $B$, Jurkat cells were incubated with anti-Fas antibody as described in Materials and Methods. An increase in p55 was observed. $\beta$-Actin was not detected on these blots.

within intermediate and dorsal horn and in some large neurons within ventral horn (Fig. 1A,B). Over 12-24 hr the number of red neurons increased throughout gray matter (Fig. 1C,D), although laminae I and II of dorsal horn were relatively spared. White matter axonal degeneration was found only in the most severely damaged spinal cord (10\% of total animals at $24 \mathrm{hr}$ ). Myelin and glial cells were relatively preserved early on at $6 \mathrm{hr}$ (Fig. $1 A$ ) and at $5 \mathrm{~d}$ as detected by Luxol fast blue and $\mathrm{H} \& \mathrm{E}$ staining, respectively.

\section{Caspase-8 mRNA}

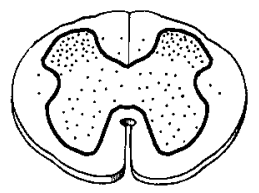

Caspase-3 p20

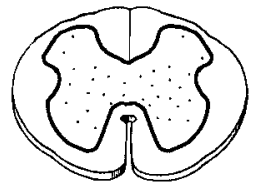

Procaspase-8

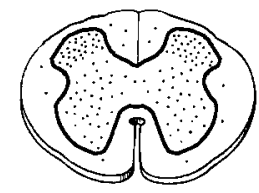

Fas

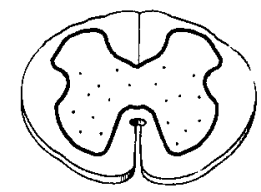

Caspase-8 p18

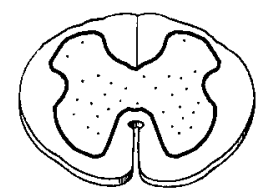

TUNEL
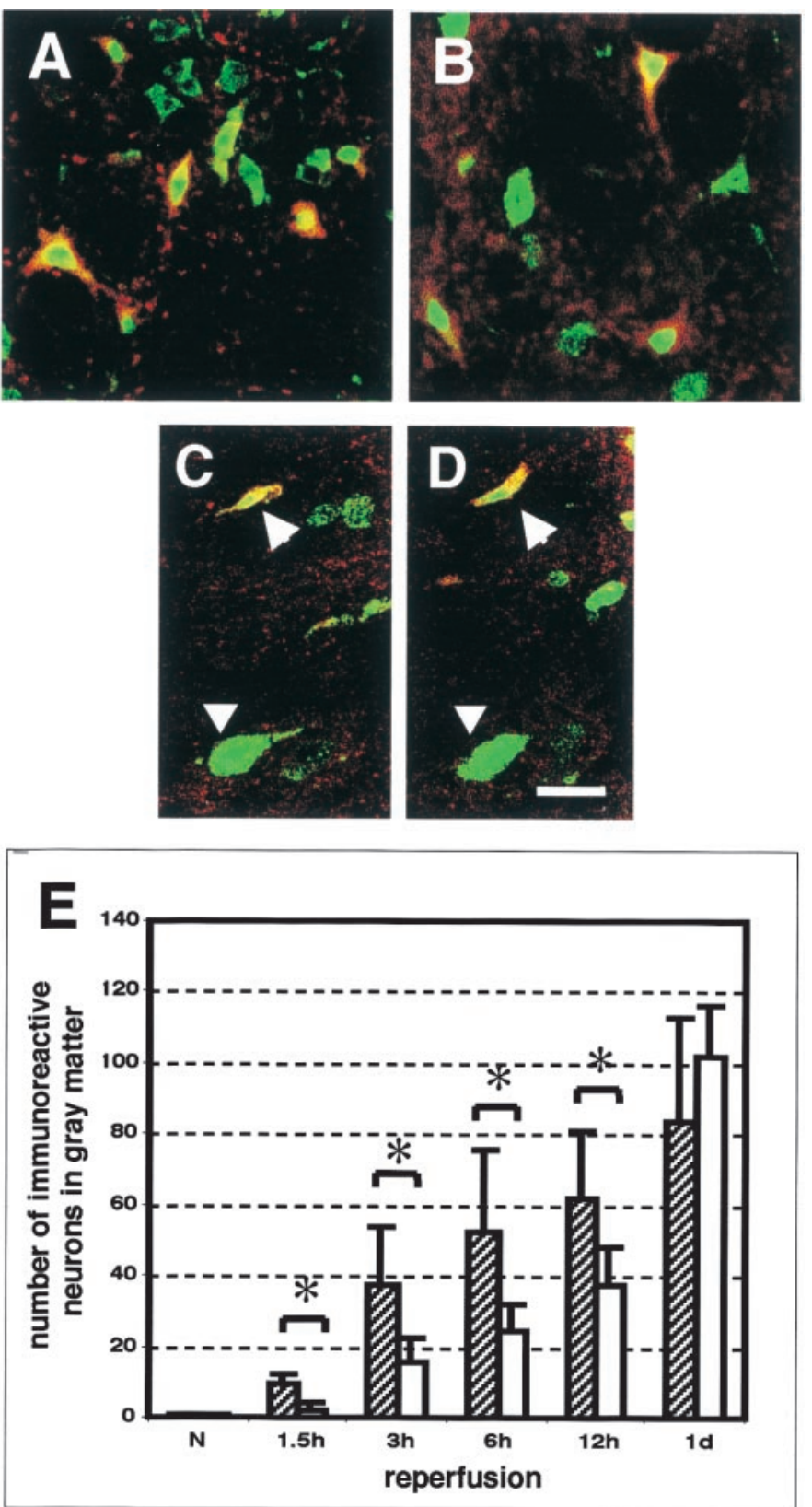

Figure 6. Caspase- 8 p18 and caspase-3 p20 in ischemic spinal neurons. Caspase-8 p18 $(A)$ and caspase-3 p20 $(B)$ immunoreactivity was detected in the cytoplasm of ischemic spinal neurons within the intermediate area $6 \mathrm{hr}$ after reperfusion. Neurons were stained by NeuN (green). $C, D$, Both caspase-8 p18 (C, arrow) and caspase-3 p20 (D, arrow) were detected in single cells within anterior horn $6 \mathrm{hr}$ after reperfusion. Arrowheads point to an identical NeuN-positive cell. Scale bar, $20 \mu \mathrm{m}$. E. The number of caspase-8 p18-positive neurons ( filled bars) was significantly greater than that of caspase-3 p20 neurons (open bars) before $12 \mathrm{hr}$ after reperfusion. The mean number of immunoreactive neurons was at the L1 level from three different mice ( $n=3$ per time point). ${ }^{*} p<0.05$ (ANOVA with Bonferroni's post hoc analysis, mean $\pm \mathrm{SD})$.

\section{Caspase-8 expression in normal spinal cord}

The proform (p55) caspase- 8 was found in gray matter neurons within NeuN-positive cells (Fig. 2A). (Note that NeuN staining was both extranuclear and nuclear in spinal neurons.) Only infrequently were procaspase-8-positive cells found in white matter. A band corresponding to the proform (p55) was constitutively expressed in normal mouse spinal cord homogenates (Fig. 2D).

Caspase-8 mRNA was also detected in normal spinal cord. Hybridization of a caspase- 8 oligonucleotide probe was readily
Figure 5. Schematic diagrams showing the density and distribution of p20, Fas, and TUNEL in spinal cord at L1, $1 \mathrm{~d}$ after reperfusion. The dots represent the relative frequency of positive cells. Schematics are representative of at least six animals each. positive cells for caspase-8 mRNA, procaspase-8, caspase- 8 p18, caspase-3

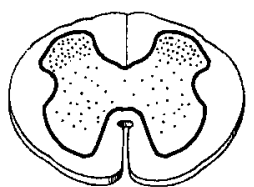


A

Figure 7. A, Appearance of active caspase-8 and caspase-3 in TUNEL-positive cells. Caspase-8 p18 (top panels) and caspase-3 p20 (bottom panels) are shown in the intermediate gray matter $1 \mathrm{~d}$ after reperfusion. Scale bar, $20 \mu \mathrm{m}$. $B$, DNA laddering was observed in ischemic spinal cord tissue $1 \mathrm{~d}$ after reperfusion. Arrows indicate bands in multiples of $180 \mathrm{bp}$ DNA fragments. $C$, Cytochrome $c$ (Cyt. c) was released into the cytosol $1 \mathrm{~d}$ after reperfusion. In control, cytochrome oxidase subunit I (Cox. I) was present in the membrane fraction and was not detectable in the cytoplasmic fraction. $\alpha$-Tubulin was used as an internal standard. $D$, Gelsolin $(86 \mathrm{kDa})$ was cleaved $1 \mathrm{~d}$ after reperfusion, compatible with cleavage by caspase-3. $\alpha$-Tubulin was used as an internal standard. $N$, Normal spinal cord. This gel is representative of four.

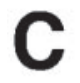

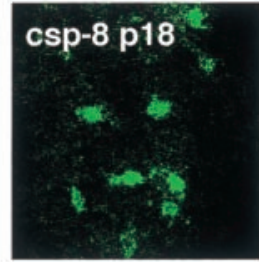
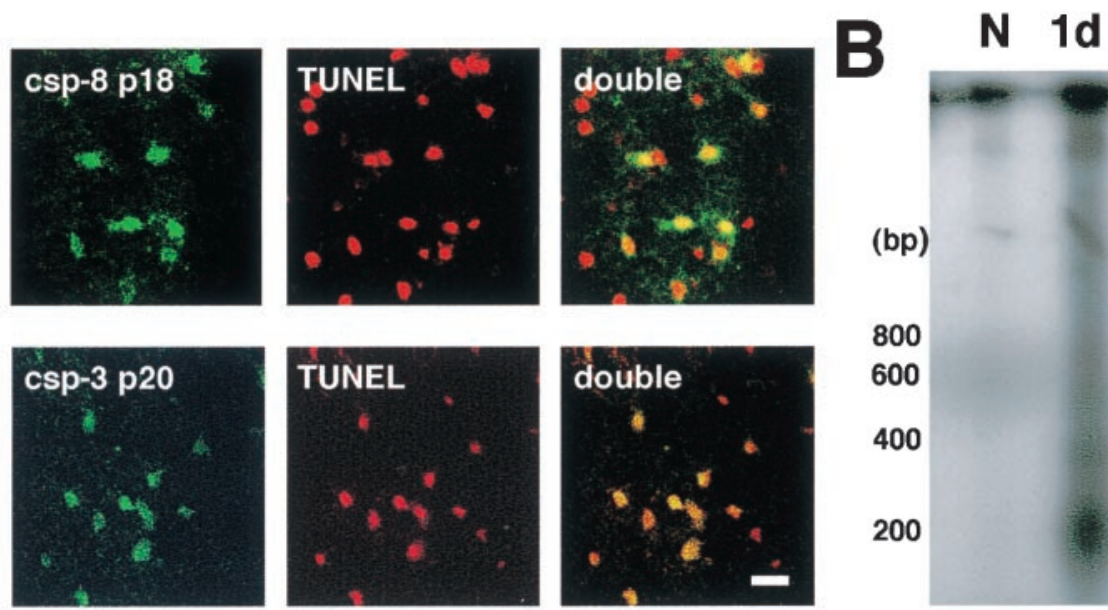

(bp)

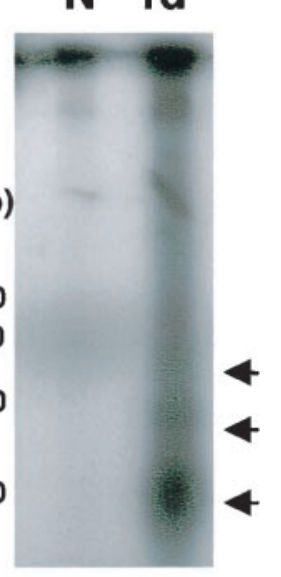

cytosol membrane

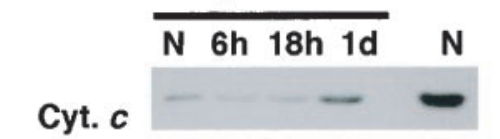

Cox. I

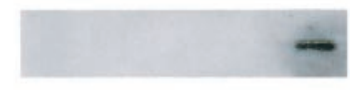

$\alpha$-tubulin

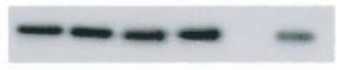

D

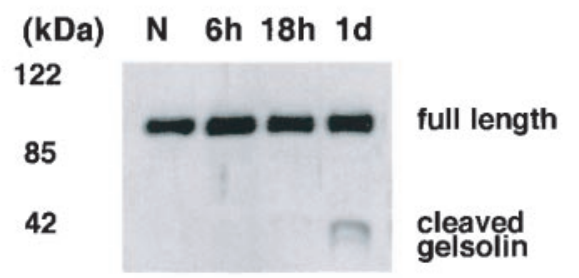

$\alpha$-tubulin detectable in normal gray matter with rare hybridization signal in white matter (Fig. 2B). The distribution and morphology of labeled cells were similar to those expressing caspase- 8 immunoreactivity. Constitutive caspase- 8 mRNA expression was confirmed by RTPCR (Fig. 2C). A single amplified product of predicted size (545 bp) was detected, and full sequence analysis confirmed that this 545 bp fragment was identical to the known sequence of mouse caspase-8 mRNA (GenBank accession number AJ 000641).

\section{Fas- and death-inducing signaling complex formation in spinal cord}

Because ligation of the Fas receptor resides upstream of caspase- 8 activation, we evaluated normal and ischemic cord for evidence of Fas receptor expression. Constitutive Fas expression was observed in medium- and large-sized neurons within intermediate or ventral horn in normal spinal cord. Microvessels were also Fas-positive. The staining was detected prominently near the outer cell membrane (Fig. 3A). After ischemia, the number and intensity of Fas-positive cells increased, and this was confirmed by immunoblot (Fig. $3 B$ ). Fas immunoreactivity was found in $<10 \%$ of procaspase 8 positive neurons before ischemia and in $10-20 \%$ of procaspase-8positive neurons after ischemia (Fig. 3C, top panels). In contrast, Fas immunoreactivity colocalized with $>50 \%(51 \pm 14 \%$ at $6 \mathrm{hr})$ of p18-positive neurons after ischemia (Fig. 3C, bottom panels).

We found a complex containing Fas and procaspase- 8 in ischemic spinal cord (Fig. 4). Probing for the complex by first incubating with antibodies against procaspase- 8 and probing the immunoprecipitants using Fas antibody, we found Fas (p45) increased after ischemia. The total p55 (Fig. 1D) and Fas (data not shown) did not change in spinal cord homogenate at 3 and $12 \mathrm{hr}$. Similar data were observed with Fas immunoprecipitation followed by probing with procaspase- 8 antibody. In this instance, a band corresponding to p55 was detected. By contrast, $\beta$-actin did not appear on these immunoblots, thereby emphasizing the specificity of the findings (data not shown). When Jurkat cells were activated by Fas ligation in vitro, the formation of a complex was detected using these antisera (Fig. 4B). Bands corresponding to Fas (p45) and procaspase-8 (p55) were present in the same location as blots from spinal cord. Hence, spinal cord ischemia appears to augment the death-inducing signaling complex. Using two different commercial antisera (FADD S-18, Santa Cruz; and AAP-211, Stressgen), FADD (a DISC component) was not detectable in Jurkat cells or spinal cord, probably because of insensitive reagents.

\section{Caspase-8 and caspase-3 activation and TUNEL staining after ischemia}

After demonstrating formation of a complex containing Fas receptor and procaspase- 8 , we next examined for caspase- 8 and caspase- 3 cleavage after spinal cord ischemia. Procaspase- 8 immunoreactivity became more intense and more widespread in neurons throughout gray matter (data not shown), although the band did not change on immunoblotting (Fig. 2D). Caspase-8 mRNA hybridization signal was strongly increased $1 \mathrm{~d}$ after reperfusion (Fig. $2 B$ ) and showed a distribution pattern similar to enhanced p55 immunoreactivity (Fig. 5). The increase was evident as early as $3 \mathrm{hr}$ and remained elevated as late as $1 \mathrm{~d}$ after reperfusion as detected by semiquantitative RT-PCR (Fig. $2 C$ ). The p18 cleavage product was detected by immunoblot sometime between 6 and $18 \mathrm{hr}$ and increased $1 \mathrm{~d}$ after reperfusion (Fig. $2 D$ ). The specificity of the p55 or p18 band was confirmed by preincubation with full-length human caspase- 8 or fully cleaved human caspase- 8 , respectively (data not shown).

Immunohistochemical evidence for the caspase- 8 cleavage product (p18) appeared in neurons within ischemic ventral gray and intermediate zone (Fig. $6 A$ ); procaspase-3 cleavage product $(\mathrm{p} 20)$ was also identified within the same regions (Fig. $6 B$ ). Some p18labeled cells contained p20 immunoreactivity as detected in adjacent sections at $6 \mathrm{hr}$ (Fig. 6C,D). The number of caspase-8- and 
-3-labeled cells increased over time, although the number of p18positive neurons was significantly higher until $12 \mathrm{hr}$ (Fig. 6E). The anatomical distribution of active caspase-8- and caspase-3-positive neurons was overlapping (Fig. 5).

To assess DNA damage, TUNEL staining and agarose gel electrophoresis were performed. TUNEL-positive cells appeared in dorsal horn and intermediate and medial aspects of ventral gray matter between $18 \mathrm{hr}$ and $1 \mathrm{~d}$ (Fig. 7A,B). Activated caspases appeared within neurons showing evidence of DNA damage. Within ventral horn and intermediate gray matter, p18-labeled cells colocalized with NeuN (Fig. 6A) and TUNEL-positive cells (Fig. $7 A$, top panels). Most $\mathrm{p} 20$-labeled cells colocalized within TUNELpositive cells (Fig. 7A, bottom panels). The number of TUNELpositive cells containing p18 or p20 immunoreactivity was $66 \pm 7$ or $79 \pm 7 \%$, respectively within ventral horn and intermediate gray matter. There were very few p18- and p20-positive cells within superficial dorsal horn despite numerous TUNEL-positive cells (Fig. 5). DNA laddering was also detected (180-200 bp fragments; Fig. 7B). TUNEL-positive cells were mostly neurons, because they contained NeuN but not GFAP immunoreactivity (data not shown).

\section{Cytochrome $c$ release and gelsolin cleavage after ischemia}

We studied cytochrome $c$ release and cleavage of gelsolin to provide additional evidence for the importance of caspase-mediated mechanisms. Cytochrome $c$ appeared prominently in the cytoplasm $1 \mathrm{~d}$ after reperfusion with trace amounts at earlier time points, which did not differ from those of the nonischemic control (Fig. 7C). Cytochrome oxidase subunit I, present in the membrane fraction, was not detectable in the cytoplasmic fraction. Gelsolin (p86), a substrate cleaved by activated caspases, was cleaved $1 \mathrm{~d}$ after reperfusion (Fig. 7D).

\section{DISCUSSION}

We used a novel model of spinal cord ischemia to study activation of caspases and to examine the possibility of a caspase-mediated cascade promoting cell death. We identified both Fas and procaspase-8 within single neurons in normal lumbar spinal cord, including motoneurons as well as other overlapping populations of NeuN-positive cells expressing Fas (Fig. $3 A$ ) or procaspase- 8 within normal spinal gray matter (Fig. $2 A$ ). Constitutive Fas expression was also found infrequently in non-neuronal cells (principally blood vessels), whereas procaspase- 8 was constitutively expressed almost exclusively in neurons. Shortly after reversible ischemia $(3 \mathrm{hr})$, we detected colocalization of Fas receptor with cleaved caspase- 8 plus enhanced procaspase 8 turnover (RT-PCR and in situ hybridization; Fig. 2B,C). Procaspase- 8 cleavage was reported by Velier et al. (1999) in mouse cortical gray matter neurons after permanent middle cerebral artery occlusion. Hence, ischemia triggers caspase 8 cleavage in spinal cord as well as within brain.

The coexistence of procaspase- 8 and Fas within single cells raised the possibility that the Fas receptor may lie upstream of caspase- 8 activation in spinal neurons. Ligation or oligomerization of Fas promotes formation of a DISC by recruiting and then activating procaspase- 8 in tissues (Yin et al., 1999) and cells (Ferrari et al., 1998; Scaffidi et al., 1998; Feldenberg et al., 1999). We reasoned that if ischemia triggered formation of a death receptor complex, we would detect an increase in Fas afterng immunoprecipitation with p55 antibody and vice versa (Fig. $4 A$ ). We detected such changes on immunoblots after interruption of the blood supply to spinal cord (Fig. 4). These findings resembled what we observed after anti-CD95 antibody incubation with Jurkat cells (Fig. 4) and together point to the probability of an important upstream receptor-driven mechanism for caspase activation after spinal cord injury. Consistent with these findings in spinal cord, Fas and FasL become upregulated after cerebral ischemia, and $l p r$ mice expressing dysfunctional Fas develop smaller lesions after reversible middle cerebral artery occlusion (Martin-Villalba et al., 1999).

The expression of Fas and caspase- 8 has not been studied extensively in adult spinal cord, although in ischemic brain, increased mRNA was reported previously (Matsuyama et al., 1995). More is known about the developing nervous system. For example, Fas receptor mRNA, its antigen, and associated proteins are upregulated during the peak apoptosis in embryonic brain (Cheema et al., 1999), and this neuronal Fas receptor is functional as a death receptor (Felderhoff-Mueser et al., 2000). Moreover, Fas expression upregulates after cerebral hypoxic-ischemic injury in developing rat brain. In cultured embryonic motoneurons expressing Fas and FasL, programmed cell death is triggered via Fas death receptors, abrogated by isoleucine-glutamic acid-threonine-aspartic acid, a caspase 8 inhibitor, or by upregulation of an endogenous caspase 8 inhibitor. Together these data indicate that death of embryonic spinal neurons is triggered through the Fas death receptor (Raoul et al., 1999). Besides neurons, Fas is reportedly expressed in astrocytes (Bechmann et al., 1999) and microglia (Vogt et al., 1998) in adult nervous system, although there was little evidence for this in ischemic spinal cord at the examined time points.

In addition to the possibility of DISC formation, other evidence points to the importance of caspases- 8 and -3 in ischemic cell death within spinal neurons. In our studies, co-localization of the caspase-3 cleavage product (p20) was detected in a subpopulation of p18-containing neurons. Assuming that both antibodies bind antigen with equal sensitivity (and knowing that caspase- 3 is more abundantly expressed in nervous tissue; M. A. Moskowitz, unpublished observation), the data could indicate ischemia-induced sequential activation of procaspase- 8 and procaspase- 3 within spinal cord. Moreover, a substantial proportion of cells expressing active caspases were also TUNEL-positive (Fig. 7A). Sixty-six percent of TUNEL-positive cells contained caspase- 8 p18, whereas an even larger percentage (79\%) contained both TUNEL and caspase-3 p20 staining, again suggesting that these caspase family members are co-expressed and important for cell death in spinal cord. Involvement of other executioner caspases or non-caspase-mediated mechanisms may explain why apoptotic-like cell death developed within dorsal horn without caspase cleavage- 8 or -3 (p18- or p20-stained cells). More studies are needed to clarify this point. From these data, we conclude that caspase-mediated mechanisms of cell death are prominent in spinal cord ischemia, and that caspase- 8 and caspase- 3 activation promote cell death in an overlapping cell population within intermediate and ventral gray matter.

Several studies suggest the significance of caspase-mediated cell death in models of ischemia. For example, cell loss induced by traumatic (Crowe et al., 1997; Liu et al., 1997) or ischemic (Kato et al., 1997; Mackey et al., 1997; Hayashi et al., 1998; Sakurai et al., 1998) spinal cord injury may be attributed, at least in part, to apoptotic mechanisms. Recently Springer et al. (1999) reported that caspase-3 enzymatic activity increases as early as $1 \mathrm{hr}$ after spinal cord trauma, along with cytochrome $c$ release and caspase- 9 processing. We observed cytochrome $c$ release from mitochondria and cleavage of gelsolin (Fig. $7 C, D$ ), a caspase- 3 substrate, suggesting the importance of mitochondrial-dependent mechanisms ( $\mathrm{Li}$ et al., 1997; Krajewski et al., 1999). Caspases are also activated in models of both global and focal cerebral ischemia. In models of reversible occlusion, onset of caspase cleavage is directly related to the intensity and severity of ischemia. After $2 \mathrm{hr}$ of middle cerebral artery filament occlusion, caspase- 3 cleavage appears within 5 min of reperfusion (Namura et al., 1998), whereas activation is first observed $\sim 9 \mathrm{hr}$ after reperfusion after $30 \mathrm{~min}$ of ischemia (Fink et al., 1998). In both focal models, mitochondrial release of cytochrome $c$ anticipates or is concurrent with caspase activation. Using the same antisera in spinal cord homogenates, we noted that cytosolic cytochrome $c$ appeared relatively delayed ( $24 \mathrm{hr}$ ) when compared with the onset of caspase activation, possibly indicating a predominance of type I cell death early on (Scaffidi et al., 1998). 
In conclusion, we demonstrated that ischemia augmented association of key proteins within a DISC complex. In addition to this novel in vivo finding, we also provided evidence for caspase- 8 and caspase- 3 activation in neurons undergoing cell death. Consistent with published in vitro data, our findings support the notion that death receptors lie upstream of caspase- 8 and -3 , because Fas receptors were expressed in p18-positive cells, and many of these cells were TUNEL- and p20-positive. Because data from other ischemia models provide evidence that caspase- 3 is cleaved before irreversible cell damage (Hara et al., 1997; Fink et al., 1998; Chen et al., 1998; Endres et al., 1998), caspase inhibitors may prove useful for treating ischemic spinal cord injury and other CNS conditions in which apoptotic-like cell death may be important (e.g., trauma and degenerative disease).

\section{REFERENCES}

Adachi M, Watanabe-Fukunaga R, Nagata S (1993) Abberant transcription caused by the insertion of an early transposable element in an intron of the Fas antigen gene of lpr mice. Proc Natl Acad Sci USA 90:1756-1760.

Bechmann I, Mor G, Nilson J, Eliza M, Nitsch R, Naftolin F (1999) FasL (CD95L, Apo1L) is expressed in the normal rat and human brain: evidence for the exsistence of an immunological brain barrier. Glia 27:62-74.

Boldin MP, Goncharov TM, Goltsev YV, Wallach D (1996) Involvement of MACH, a novel MORT1/FADD-interacting protease, in Fas/APO-1and TNF receptor-induced cell death. Cell 85:803-815.

Bossy-Wetzel E, Newmeyer DD, Green DR (1998) Mitochondrial cytochrome c release in apoptosis occurs upstream of DEVD-specific caspase activation and independently of mitochondrial transmembrane depolarization. EMBO J 17:37-49.

Cheema ZF, Wade SB, Sata M, Walsh K, Sohrabji F, Miranda RC (1999) Fas/Apo [Apoptosis]-1 and associated proteins in the differentiating cerebral cortex: induction of casapse-dependent cell death and activation of NF- $\kappa$ B. J Neurosci 19:1754-1770.

Chen J, Nagayama T, Jin K, Stetler A, Zhu RL, Graham SH, Simon RP (1998) Induction of caspase-3-like protease may mediate delayed neuronal death in the hippocampus after transient cerebral ischemia. J Neurosci 18:4914-4928.

Cheshire WP, Santos CC, Massey EW, Howard JF Jr (1996) Spinal cord infarction: etiology and outcome. Neurology 47:321-330.

Crowe MJ, Bresnahan C, Shuman SL, Masters JN, Beattie MS (1997) Apoptosis and delayed degeneration after spinal cord injury in rats and monkeys. Nat Med 3:73-76.

Endres M, Namura S, Shimizu-Sasamata M, Waeber C, Zhang L, GømezIsla T, Hyman BT, Moskowitz MA (1998) Attenuation of delayed neuronal death after mild focal ischemia in mice by inhibition of the caspase family. J Cereb Blood Flow Metab 18:238-247.

Feldenberg LR, Thevananther S, del Rio M, de Leon M, Devarajan P (1999) Partial ATP depletion induces Fas- and caspase-mediated apoptosis in MDCK cells. Am J Physiol 276:F837-F846.

Felderhoff-Mueser U, Taylor DL, Greenwood K, Kozma M, Stibenz D, Joashi UC, Edwards AD, Mehmet H (2000) Fas/CD95/APO-1 can function as a death receptor for neuronal cells in vitro and in vivo and is upregulated following cerebral hypoxic-ischemic injury to the developing rat brain. Brain Pathol 10:17-29.

Fernandes-Alnemri T, Armstrong RC, Krebs J, Srinivasula SM, Wang L, Bullrich F, Fritz LC, Trapani JA, Tomaselli KJ, Litwack G, Alnemri ES (1996) In vitro activation of CPP32 and Mch3 by Mch4, a novel human apoptotic cysteine protease containing two FADD-like domains. Proc Natl Acad Sci USA 93:7464-7469.

Ferrari D, Stepczynska A, Los M, Wesselborg S, Schulze-Osthoff K (1998) Differential regulation and ATP requirement for caspase- 8 and caspase-3 activation during CD95- and anticancer drug-induced apoptosis. J Exp Med 188:979-984.

Fink K, Zhu J, Namura S, Shimizu-Sasamata M, Endres M, Ma J, Dalkara T, Yuan J, Moskowitz MA (1998) Prolonged therapeutic window for ischemic brain damage caused by delayed caspase activation. J Cereb Blood Flow Metab 1998:1071-1076.

Garcia JH, Liu KF, Ho KL (1995) Neuronal necrosis after middle cerebral artery occlusion in Wistar rats progresses at different time intervals in the caudoputamen and the cortex. Stroke 26:636-643.

Gavrieli Y, Sherman Y, Ben-Sasson SA (1992) Identification of programmed cell death in situ via specific labeling of nuclear DNA fragmentation. J Cell Biol 119:493-501.

Hara H, Friedlander RM, Gagliardini V, Ayata C, Fink K, Huang Z, Shimizu-Sasamata M, Yuan J, Moskowitz MA (1997) Inhibition of in- terleukin 1-converting enzyme family proteases reduces ischemic and excitotoxic neuronal damage. Proc Natl Acad Sci USA 94:2007-2012.

Hayashi T, Sakurai M, Abe K, Sadahiro M, Tabayashi K, Itoyama Y (1998) Apoptosis of motor neurons with induction of caspases in the spinal cord after ischemia. Stroke 29:1007-1013.

Kato H, Kanellopoulos GK, Matsuo S, Wu YJ, Jacquin MF, Hsu CY, Choi DW, Kouchoukos NT (1997) Protection of rat spinal cord from ischemia with dextrorphan and cycloheximide: effects on necrosis and apoptosis. J Thorac Cardiovasc Surg 114:609-618.

Kischkel FC, Hellbardt S, Behrmann I, Germer M, Pawlita M, Krammer PH, Peter ME (1995) Cytotoxicity-dependent APO-1 (Fas/CD95)associated proteins form a death-inducing signaling complex (DISC) with the receptor. EMBO J 14:5579-5588.

Kothakota S, Azuma T, Reinhard C, Klippel A, Tang J, Chu K, McGarry TJ, Kirschner MW, Koths K, Kwiatkowski DJ, Williams LT (1997) Caspase-3-generated fragment of gelsolin: effector of morphological change in apoptosis. Science 278:294-298.

Kouchoukos NT (1991) Spinal cord ischemic injury: is it preventable? Semin Thorac Cardiovasc Surg 3:323-328.

Krajewski S, Krajewska M, Ellerby LM, Welsh K, Xie Z, Deveraux QL, Salvesen GS, Bredesen DE, Rosenthal RE, Fiskum G, Reed JC (1999) Release of caspase- 9 from mitochondria during neuronal apoptosis and cerebral ischemia. Proc Natl Acad Sci USA 96:5752-5757.

Kuida K, Zheng TS, Na S, Kuan C, Yang D, Karasuyama H, Rakic P, Flavell RA (1996) Decreased apoptosis in the brain and premature lethality in CPP-32 deficient mice. Nature 384:368-372.

Kuwana T, Smith JJ, Muzio M, Dixit V, Newmeyer DD, Kornbluth S (1998) Apoptosis induction by caspase- 8 is amplified through the mitochondrial release of cytochrome $c$. J Biol Chem 273:16589-16594.

Lang-Lazdunski L, Matsushita K, Hirt L, Waeber C, Vonsattel JPG, Moskowitz MA (2000) Spinal cord ischemia: development of a model in the mouse. Stroke 31:208-213.

Li P, Nijhawan D, Budihardjo I, Srinivasula SM, Ahmad M, Alnemri ES, Wang X (1997) Cytochrome c and dATP-dependent formation of Apaf$1 /$ caspase-9 complex initiates an apoptotic protease cascade. Cell 91:479-489.

Liu XZ, Xu XM, Hu R, Du C, Zhang SX, McDonald JW, Dong HX, Wu YJ, Fan GS, Jacquin MF, Hsu CY, Choi DW (1997) Neuronal and glial apoptosis after traumatic spinal cord injury. J Neurosci 17:5395-5406.

Los M, de Craen MV, Penning LC, Schenk H, Westendorp M, Baeuerle PA, Drîge W, Krammer PH, Fiers W, Schulze-Osthoff K (1995) Requirement of an ICE/CED-3 protease for Fas/APO-1-mediated apoptosis. Nature 375:81-83.

Mackey ME, Wu Y, Hu R, DeMaro JA, Jacquin MF, Kanellopoulos GK, Hsu CY, Kouchoukos NT (1997) Cell death suggestive of apoptosis after spinal cord ischemia in rabbits. Stroke 28:2012-2017.

Martin-Villalba A, Herr I, Jeremias I, Hahne M, Brandt R, Vogel J, Schenkel J, Herdegen T, Debatin KM (1999) CD95 ligand (Fas-L/APO$1 \mathrm{~L})$ and tumor necrosis factor-related apoptosis-inducing ligand mediate ischemia-induced apoptosis in neurons. J Neurosci 19:3809-3817.

Matsuyama T, Hata R, Yamamoto Y, Tagaya M, Akita H, Uno H, Wanaka A, Furuyama J, Sugita M (1995) Localization of Fas antigen mRNA induced in postischemic murine forebrain by in situ hybridization. Mol Brain Res 34:166-172.

Medema JP, Scaffidi C, Kischkel FC, Shevchenko A, Mann M, Krammer PH, Peter ME (1997) FLICE is activated by association with the CD95 death-inducing signaling complex (DISC). EMBO J 16:2794-2804.

Muzio M, Chinnaiyan AM, Kischkel FC, O'Rourke K, Shevchenko A, Ni J, Scaffidi C, Bretz JD, Zhang M, Gentz R, Mann M, Krammer PH, Peter ME, Dixit VM (1996) FLICE, a novel FADD-homologous ICE/CED3-like protease, is recruited to the CD95 (Fas/APO-1) death-inducing signaling complex. Cell 85:817-827.

Nagata S (1997) Apoptosis by death receptor. Cell 88:355-365.

Nagata S, Goldstein P (1995) The Fas receptor. Science 267:1449-1456.

Namura S, Zhu J, Fink K, Endres M, Srinivasan A, Tomaselli KJ, Yuan J, Moskowitz MA (1998) Activation and cleavage of caspase-3 in apoptosis induced by experimental cerebral ischemia. J Neurosci 18:3659-3668.

Raoul C, Henderson CE, Pettmann B (1999) Programmed cell death of embryonic motoneurons triggered through the Fas death receptor. J Cell Biol 147:1049-1061.

Sakamaki K, Tsukumo S, Yonehara S (1998) Molecular cloning and characterization of mouse caspase-8. Eur J Biochem 253:399-405.

Sakurai M, Hayashi T, Abe K, Sadahiro M, Tabayashi K (1998) Delayed and selective motor neuron death after transient spinal cord ischemia: a role of apoptosis? J Thorac Cardiovasc Surg 115:1310-1315.

Scaffidi C, Fulda S, Srinivasan A, Friesen C, Li F, Tomaselli KJ, Debatin KM, Krammer PH, Peter ME (1998) Two CD95 (APO1/Fas) signaling pathways. EMBO J 17:1675-1687.

Slee EA, Harte MT, Kluck RM, Wolf BB, Casiano CA, Newmeyer DD, Wang HG, Reed JC, Nicholson DW, Alnemri ES, Green DR, Martin SJ (1999) Ordering the cytochrome c-initiated caspase cascade: hierarchial activation of caspases-2, $-3,-6,-7,-8$, and -10 in a caspase-9-dependent manner. J Cell Biol 144:281-292.

Springer JE, Azbill RD, Knapp PE (1999) Activation of the caspase-3 apoptotic cascade in traumatic spinal cord injury. Nat Med 5:943-946.

Srinivasan A, Roth KA, Sayers RO, Shindler KS, Wong AM, Fritz LC, Tomaselli KJ (1998) In situ immunodetection of activated caspase-3 in 
apoptotic neurons in the developing nervous system. Cell Death Differ 5:1004-1016.

Srinivasula SM, Ahmad M, Fernandes-Alnemri T, Litwack G, Alnemri ES (1996) Molecular ordering of the Fas-apoptotic pathway: the Fas/ APO-1 protease Mch5 is a CrmA-inhibitable protease that activates multiple Ced-3/ICE-like cysteine proteases. Proc Natl Acad Sci USA 93:14486-14491.

Stennicke HR, Jårgensmeier JM, Shin H, Deveraux Q, Wolf BB, Yang X, Zhou Q, Ellerby HM, Ellerby LM, Bredesen D, Green DR, Reed JC, Froelich CJ, Salvesen GS (1998) Pro-caspase-3 is a major physiologic target of caspase-8. J Biol Chem 273:27084-27090.

Stroh C, Schulze-Osthoff K (1998) Death by a thousand cuts: an ever increasing list of caspase substrates. Cell Death Differ 5:997-1000.

Tilly JL, Hsueh AJW (1993) Microscale autoradiographic method for the qualitative and quantitative analysis of apoptotic DNA fragmentation. J Cell Physiol 154:519-526.
Velier JJ, Ellison JA, Kikly KK, Spera PA, Barone FC, Feuerstein GZ (1999) Caspase- 8 and caspase-3 are expressed by different populations of cortical neurons undergoing delayed cell death after focal stroke in the rat. J Neurosci 19:5932-5941.

Vogt M, Bauer MK, Ferrari D, Schulze-Osthoff K (1998) Oxidative stress and hypoxia-reoxygenation trigger CD95 (APO-1/Fas) ligand expression in microglial cells. FEBS Lett 429:67-72.

Von Oppel UO, Dune TT, De Groot MK, Zilla P (1994) Traumatic aortic rupture: twenty-year metaanalysis of mortality and risk of paraplegia. Ann Thorac Surg 58:585-593.

Woo M, Hakem A, Elia AJ, Hakem R, Duncan GS, Patterson BJ, Mak TW (1999) In vivo evidence that caspase-3 is required for Fas-mediated apoptosis of hepatocytes. J Immunol 163:4909-4916.

Yin XM, Wang K, Gross A, Zhao Y, Zinkel S, Klocke B, Roth KA, Korsmeyer SJ (1999) Bid-deficient mice are resistent to Fas-induced hepatocellular apoptosis. Nature 400:886-891. 